\title{
Study of hedonistic lifestyles based on sexes and cultural background
}

\author{
Ristra Sandra Ritonga1, Muhammad Fadlil², Agung Tri Prasetia ${ }^{3}$, Muhammad \\ Rifat Affani ${ }^{4}$ \\ 1234 Universitas Negeri Padang, Padang - Indonesia, (ristrasandraritonga18@gmail.com)
}

\begin{abstract}
This research aims at investigating the varieties of hedonistic lifestyles adopted by university students based on their sexes and cultural backgrounds. Culture is referred to in this research is the culture of Batak and Minang culture. The formulation of the problem in this research is there any difference in the lifestyle of hedonism in terms of gender and culture. This research method using descriptive quantitative. The sample in this study were students numbered 80 people. Data collection techniques in this study using a questionnaire about the behavior of hedonism. Data were analyzed using t-test. based on testing and data analysis significance level of $<0.005$. Namely, the hedonistic lifestyle in terms of gender has the significance of 0.000 , and the lifestyle of hedonism in terms of culture has a significance of 0.005 . This means that there are differences in terms hedonistic lifestyle of sex and Minang and Batak culture at the level of students.
\end{abstract}

Keywords: hedonism, sex, and culture

\section{Introduction}

Of Youth is one of the periods of the most enjoyable. Many say that adolescence should be enjoyed as much as possible because adolescence is the most beautiful of its time. However, in the phase teens, a tremendous period ranges and crisis. Because, basically, adolescence is a time refinement of the stages of development before adolescence. Teenagers who are referred to in the lives of people in Indonesia have an age limit between 11 and 24 years old and not yet married individuals (Sumanto, 2014).

During the past modren is one where there is a shift in attitude and mentality as citizens to be able to live as the demands of the present which at any time evolving with the times increasingly intense (Bernatta, 2017). Modernists influence or impact of globalization great to meet the needs of the times now the teenage lifestyle. Lifestyle is a unique way of everyone in striving for the goal especially by people in his life (Trimartati, 2014). However, as the development of the technology at this time negatively impact a teenager's life, including freer lifestyle, where teenagers are increasingly follow the lifestyle of the artists and a luxurious lifestyle. Luxury lifestyle can also be regarded as a hedonistic lifestyle (Saputra, Lester, \& Sholikhah, 2017).

The concept of well-being in accordance circuitry hedonism core values and ethics of western culture, which praised the liberal individualism (JIshanloo, 2014). A lifestyle of hedonism can be contacted with a happiness that is owned by an individual. According to the results of the individual 
research will have a high level of happiness if he had a lifestyle of hedonism or follow a lifestyle that is now again growing age (Joshanloo \& Jordan, 2016).

The results of subsequent studies also explained that the lifestyle of hedonism in adolescents in the city of Samarinda of $24.2 \%$ can be attributed to the influence of religiosity and socio-economic status of parents. Teenagers who are referred to in this study aged 15-17 years as many as 82 subjects (Nurwitasari, Imawati, \& Rosliana, 2014). Based on the analysis of the results of research conducted at the University of Ahmad Dahlan in 2011, there were 3 female students and two male students who serve as research subjects, the background factors student guidance and counseling Ahmad Dahlan University in 2011 is conformity peers and also economic status of parents (Trimartati, 2014).

Departing from the phenomenon of the hedonistic lifestyle, the researchers aim to see the difference in the lifestyle of hedonism in students are female and male and also see the difference in the lifestyle of hedonism students Batak and Minang culture. Thus, students are expected to take effect is positive to make a beneficial change at the level of hedonism life lifestyle among students.

Armstrong (2003) explains that the lifestyle of hedonism is one of the lifestyle activities aimed to seek the pleasures of life, such individuals would rather spend his time outside the house just to hang out, shopping expensive items please, to be able to do anything to become the center of attention in the surrounding neighborhood. Hedonistic lifestyle closely associated with the development of technology that is currently growing very rapidly. With the growing sophistication of technological development, the higher the lifestyle that must be followed by teenagers. Aspects of the lifestyle of hedonism (Trimartati, 2014), among others: (1) Activity. On this aspect is evident from activities that are often seen in teenagers' lives every day, like hanging out in cafes, shopping at the luxury shopping centers, to always capture the activity itself did. (2) Interest. One example in this aspect is the fashion, food, luxury objects, hangout, and always wanted to be the center of attention in the surrounding neighborhood. (3) Opinion. What is meant in this aspect is the answer to both oral and written form given in response perhaps stimulus situation in which a kind of questions.

Amrin Ra'uf (2005) also explains that each individual has their own way to anticipate the worst impact that could threaten the individual to get in on the high level of hedonism space. Adabeberapa recommended the way to anticipate the lifestyle of hedonism, which is as follows: (1) Build a good awareness. Each individual should indeed have to have a high awareness to surroundings, living in an environment that almost all of them follow the lifestyle of hedonism then as an individual to be affected then we must aware of the life we are living. (1) Utilizing a wealth become qualified. Individuals who have abundant wealth or wealth is often referred to, it will easily get what he wants. However, sometimes they are not able to use his fortune for something useful, most of them are just going to spend his fortune by buying goods that are not important. For that to avoid the lifestyle of hedonism, the individual should be able to utilize his wealth as something valuable and qualified. (1) Resist the urge to behave or follow the lifestyle of hedonism. Individuals difficult to resist a desire that they wanted even though something is not very important. However, to stop herself from hedonistic lifestyle then he will avoid hedonistic lifestyle. (1) Proceed in life. Individuals should select the step and the proper way to make a more useful life. For that man should be able to run every process of life as well as possible.

Based on the above, it can be concluded that the lifestyle of hedonism can be prevented with their building awareness of ourselves in holding anything he wants.

Indeed, hedonistic lifestyle that involves in gender and culture is mostly done by women. Because women now pay more attention to lifestyle, especially in the field of fashion. One of them as students who now live in urban areas then itself better to follow the lifestyle of hedonism that he considered there by his close friends in college (Baiduri, 2013). In contrast to the man who most of the male students are indifferent to the appearance to the campus, for men to wear comfortable clothes for him was enough to make him confident with his lifestyle (Desryani, 2015). 
Hedonism is simply the one that increases the understanding of individual preferences with a luxury in life regardless of religious prohibitions and deontology (Saputra et al., 2017). In contrast to the Batak culture still, assume that the religion and culture a unity that can not be separated. Religion and culture have a reciprocal relationship with regard to something that is related to lifestyle, and therefore hedonistic lifestyle in Batak culture Angkola still banned for violating any terms of religion (Kurniawan, 2001). However, the Minang culture on the west coast hedonistic lifestyle has begun to enter as the arrival of foreign tourists who visit the area, including the village of Java, on the west coast (Septika, Pitoewas, and Yanzi, 2015).

Through this phenomenon, researchers intend to examine differences in the hedonistic lifestyle of students in terms of gender and culture. Culture is referred to in this study is the Batak and Minang culture.

\section{Method}

This research is comparative descriptive study design with $3 \times 2$. The population is a student whose background Minang and Batak. The number of samples required in this study was 40 students and 40 students minang cultured hobo, means the sum of all the samples is 80 students. techniques used in sampling is proportional random sampling.

The instrument used in this study is the scale Likert and instrument which discusses hedonistic lifestyle. Data were analyzed using T-test data using SPSS version 20. Assistance.

\section{Results and Discussion}

The results of this research are the discovery of the level of hedonistic lifestyle which is owned by the cultured student Minang and Batak. Students with a background in Minang culture has a hedonistic lifestyle level at high category with the percentage of 71.74 and the cultural background of students Hobo also at high category with a lower percentage than students Minang cultural background, with the percentage of 68.40. If the terms of gender, female student lifestyle shows Hedonism higher than male students with a ratio of 72.40 and 67.74 percentage. And when viewed from both premises female student cultural background hedonistic lifestyle minang has the highest with 75.74 percent, and female student with a background Batak culture and male students Minang and Batak cultural background have the same percentage is 67.74.

Table 1. Distribution of descriptive data ConductHedonism based

BackgroundCulture and Gender

\begin{tabular}{lcccccc}
\hline \multicolumn{1}{c}{$\begin{array}{c}\text { Cultural } \\
\text { Background }\end{array}$} & \multicolumn{2}{c}{ Male } & \multicolumn{2}{c}{ Gemale\% } & \multicolumn{2}{c}{ Total } \\
& $\%$ & Category & $\%$ & Category & Average & Category \\
Minang & 67.74 & High & 75.74 & High & 71.74 & High \\
Batak & 67.74 & high & 69.07 & high & 68.40 & high \\
average & 67.74 & high & 72.40 & high & 70.07 & high \\
\hline
\end{tabular}

Then, the difference test using T-test to see is there a difference in student hedonistic lifestyle in terms of cultural background and gender, The results of T-test showed that there were differences between the hedonistic lifestyle male student cultured Minang and Batak culture. Likewise with the lifestyle of hedonism among female undergraduates Batak and Minang culture.

1. Lifestyle minang student cultural backgrounds; cultural, community minang that embraces matrilineal where their function is more than a woman in the family make women as a figure to be applied as well as possible, including in appearance, but there must be limits values and norms 
that are owned by women minang in dress which here can be interpreted with lifestyle. The results showed the lifestyle of hedonism in a cultured student high minang. The minang culture where students want to look attractive in order to be regarded as the fashionable student an on campus.

2. Lifestyle student Batak cultural backgrounds; culturally, Batak society is a society that is famous for her hard worker. Where they are willing to laboriously in order to send their children to succeed. In addition, people Hobo also still adhere to customs and religion, they say that the customs and religion can not be separated because of mutual influence. Hobo culture hedonism lifestyle also has a high level, only the student Batak culture is not on appearance but on activities that are more often hung out with his friends just to spend time.

3. Hedonism lifestyle for students in terms of gender; can be interpreted that the hedonistic lifestyle of female students is higher, it is supported by the phenomena that female students would want to be more fashionable than male students.

4. Lifestyle cultured male students Batak and Minang culture, visible when the student hedonistic lifestyle minang cultured higher than hedonistic lifestyle male student Batak culture. It is seen that the Minang culture hedonistic lifestyle may be affected due to the influx of foreign travelers that affect their lifestyle

5. Lifestyle cultured female students Batak and Minang culture. Women are known for the lifestyle of hedonism, this is seen when in place teens today are more fulfilled by women than by men. However, if examined in terms of culture then cultured minang female students who have a lifestyle of hedonism higher than female students Batak culture.

\section{Conclusions}

Based on the findings and discussion of research results can be expressed as the following conclusions.

1. The level of student hedonistic lifestyle, in general, are in a high category.

2. The level hedonistic lifestyle of students in terms of gender differs significantly, the hedonistic lifestyle where women students are higher than male students.

3. The level of student hedonistic lifestyle in terms of cultural background, where students hedonistic lifestyle Minang culture is higher than students Batak culture.

4. No interaction gender and culture in explaining the student hedonistic lifestyle.

\section{Acknowledgments}

Based on the findings of the research, discussion, and conclusions have been put forward.

Suggestions can be recommended researchers as a follow-up to this study are as follows.

1. For students, it is expected to be able to better withstand hedonistic lifestyle that does not easily fit into the environment or affected hedonistic lifestyle.

2. For counselor at the college is suggested to provide care how good lifestyle of a student.

3. Begi further research, it is advisable to examine other aspects related to the lifestyle of hedonism and use the division of cultural characteristics that are newer or have not been investigated.

\section{References}

Baiduri, R. (2013). Pergeseran Gaya Hidup Perempuan Kota: Studi Kasus Konsumsi “Fashion” di Indonesia. Jurnal Keluarga Sehat Sejahtera, 11(22), 21-28.

Bernatta, R. (2017). Gaya hidup hedonis di kalangan remaja.

Desryani, V. (2015). Hubungan Antara Harga Diri dan Gaya Hidup Hedonisme Dengan Body Image. 
Joshanloo, M., \& Jarden, A. (2016). Individualism as the moderator of the relationship between hedonism and happiness : A study in 19 nations. PAID, 94, 149-152. https://doi.org/10.1016/j.paid.2016.01.025

Kurniawan, P. (2001). Memahami Pertautan Agama dan Budaya Studi Terhadap Tradisi Marpegepege di Batak Angkola.

Nurwitasari, Imawati, D., \& Rosliana, L. (2014). Pengaruh Religiusitas dan Status Sosial Ekonomi Orang Tua Terhadap Gaya Hidup Hedonisme pada Remaja.

Ra'uf, Amin. (2009). Shoppingsaurus. Yogyakarta: Diva Press.

Saputra, S., Lestari, R. D., \& Sholikhah, O. H. (2017). Analisis Karakter Remaja Gaul Pada Hedonisme Vlog, 3(1), 26-33.

Septika, L., Pitoewas, B., \& Yanzi, H. (2015). Hubungan Masuknya Wisatawan Asing dengan Gaya Hidup Hedonisme Remaja di Pesisir Barat.

Sugiyono. (2012). Metode Penelitian Pendidikan Pendekatan Kuantitatif, Kualitatif, dan RED. Bandung: Alfabeta.

Sumanto. (2014). Psikologi Perkembangan, Fungsi, dan Teori. Yogyakarta: CAPS.

Trimartati, N. (2014). Studi Kasus Tentang Gaya Hidup Hedonisme Mahasiswa Bimbingan dan Konseling Universitas Ahmad Dahlan, 3(1), 20-28. 